Sergej V. Korolev

Petersburg

\title{
Cenne i rzadkie polskie superekslibrisy heraldyczne ze zbiorów Biblioteki Narodowej Rosji w St. Petersburgu
}

Pośród zespolu druków zachodnioeuropejskich w Bibliotece Narodowej Rosji szczególne zainteresowanie budzą książki oznaczone superekslibrisami. Książi z polskimi superekslibrisami zostały włączone do zbiorów biblioteki w początkach jej działalności. Pochodzą one $z$ różnych źródel, nie tylko ze zbiorów biblioteki braci Załuskich.

Znaki własnościowe umieszczone na oprawach wyszczególnionych poniżej są interesujące nie tylko dla specjalistów, ale również dla miłośników ksiąg. Poszczególne obiekty opisano wedlug następującego schematu: informacje o wlaścicielu; skrócony tytuł wraz $z$ adresem wydawniczym i objętością; opis oprawy (B); noty wlasnościowe innych posesorów (Pr); obecna sygnatura Biblioteki Narodowej Rosji w St. Petersburgu (NLR).

Z badań nad książką i księgozbiorami historycznymi, 3:2009 


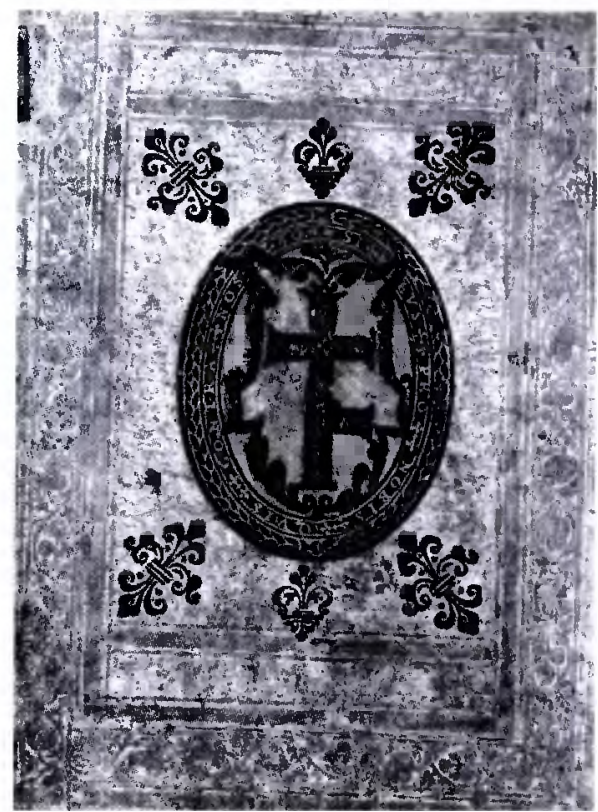

1. Bątkowski (Bątcovius, Bądkowski, Zemdalicz) Stanisław zm. 1617, herbu Prus I, syn Macieja $z$ Bądkowa. Studia: Kraków 1574, mgr artium i dr filozofii 1578, dr teologii 1603, profesor i podkanclerzy Akademii Krakowskiej, prowizor biblioteki Akademii Krakowskiej, kanonik katedralny.

Valerius (Wouters) Cornelius: Grammaticarum institutionum libri III... - Antverpiae: ex officina Christophori Plantini, 1583. $8^{\circ} .325$, [1] s.

Wspóloprawne $\mathrm{z}$ :

Valerius (Wouters) Cornelius: Tabulae, quibus totius dialecticae praecepta... exponuntur... - Antverpiae: ex officina Christophori Plantini, 1582. $8^{\circ} .104 \mathrm{~s}$.

Współoprawne $z$ :

Valerius (Wouters) Cornelius: In universam bene dicendi rationem tabula... - Antverpiae: ex officina Christophori Plantini, 1585. $8^{\circ} .104 \mathrm{~s}$.

Współoprawne z:

Valerius (Wouters) Cornelius: Ethicae, seu moralis philosophiae brevis et perspicua descriptio... - Antverpiae: ex officina Christophori Plantini, 1582. $8^{\circ} .95 \mathrm{~s}$.

Współprawne z:

Valerius (Wouters) Cornelius: De sphera, et primis astronomiae rudimentis, libellus... - Antverpiae: ex officina Christophori Plantini, 1585. $8^{\circ} .71$ s.; il.

B: skóra świńska, tłoczenie na ślepo i złotem, ślady klamer. Okladzina górna: ozdobna owalna plakieta $\mathrm{z}$ motywem arabeski. Okładzina dolna: w kartuszu herb Prus I, dewiza w otoku: Si Deus pro nobis quis contra [15]80, thoczenia: STANISLAUS BATTCOVIUS - XVI w. 
Pr.: 1. jw.

2. Ex libris Stanislai Miskiewii... 169...

3. Collegii Cracov. Soc. Jesu. 1720 [= jezuici-Kraków].

Sygnatura: NLR: 7.55.3.37.

Literatura: Katalog biskupów, pratatów i kanoników krakowskich, przez Ludwika Łętowskiego, Kraków 1852, s. 20; Katalog poloników XVI wieku Biblioteki Jagiellońskiej, tom III: Indeksy, pod red. Mariana Malickiego i Ewy Zwinogrodz-kiej, Kraków 1995, s. 244.

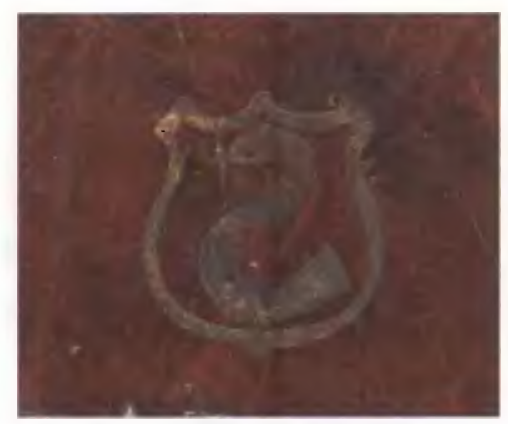

\section{Białobocki Andrzej (XVI w.),}

herbu Śreniawa (odm. bez krzyża).

Brulefer Stephanus: In reportata Stephani Brulefer super scripta sancti Bo-naventurae directorium, secundario emendatum opus... Basileae: Jacobus de Pfortzheim, 1507. $4^{\circ}$. [xx], $439 \mathrm{k}$.

Współoprawne $z$ :

Brulefer Stephanus: Formalitatum Textus una cum ipsius commento perlucido... - Basileae: Jacobus de Pfortzheim, 1507. 4 . 55, [6] k.

B: deska, skóra cielęca, toczenie na ślepo i złotem, ślady klamer. Na obu okładzinach w kartuszu herb Śreniawa (odm. bez krzyża), na okładzinie górnej tłoczenia: ANDREAS BYALOBOCZKY - XVI w.

$\mathrm{Nb}$.: herbarze notują tylko Białobockich h. Janina. Często są myleni z Bialoblockimi.

Sygnatura: NLR: 16.80 .3 .11 . 


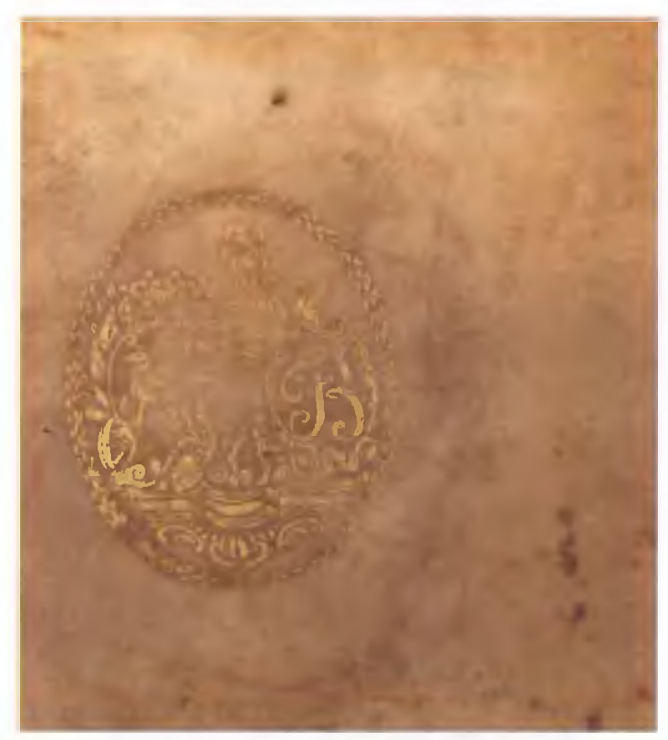

\section{Bieliński, Franciszek 1683-1766,}

herbu Junosza, marszalek nadworny, marszałek wielki koronny, kawaler orderu Orła Białego.

Plutarchus: Vitae comparatae illustrium virorum... - Basileae: apud Thomam Guarinum, 1573. $2^{\circ}$. [xii], 823, [73] s.

B: pergamin, na obu okładzinach tłoczone złotem dwie tarcze $z$ herbem Junosza oraz monogramem: F[ranciszek] B[ieliński] - XVIII w.

Pr.: 1. Jo. Georg. Trognitig, Grimens. 1690.

2. jw.

3. F[ranciszek] Bielinski [mł.] - pieczęć, XVIII w.

4. Myszkowski [Franciszek Wielopolski] - pieczęć, XVIII w.

5. Szkoła prawa - pieczęć, XIX w.

Sygnatura: NLR: 7.25.1.22.

Literatura: Polski Stownik Biograficzny (dalej PSB), t. 2, s. 47-50; Maria Sipaylło, Polskie superexlibrisy XVI-XVII wieku w zbiorach Biblioteki Uniwersyteckiej $w$ Warszawie, Warszawa 1988, tabl. 98 . 


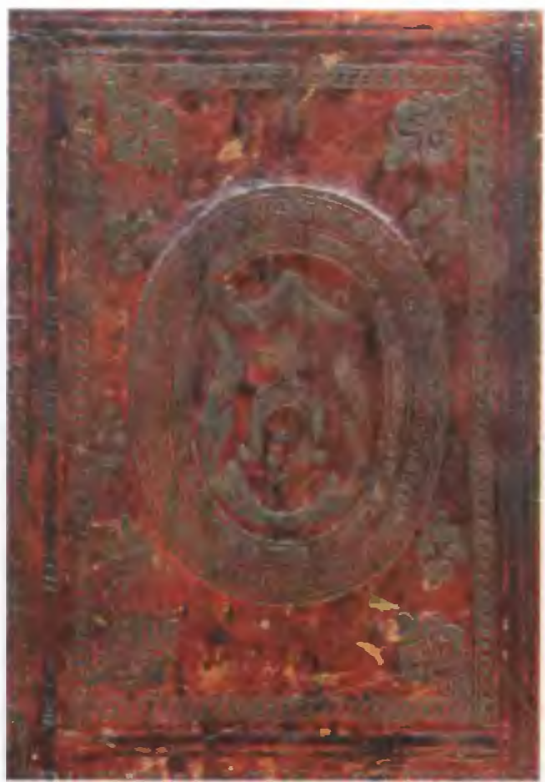

\section{Brestensis (Brzestensis, Wolski ?) Mateusz 1589,}

herbu Lubicz odm. (w podkowie zamiast krzyża cztery gwiazdy), syn Felicjana $z$ diec. włoclawskiej, studia na Akademii Krakowskiej 1583, doktor teologii.

Soto Domingo de: De iustitia et iure libri decem... - Venetiis: apud Floravantem à Prato. 1589. $4^{\circ}$. [lxiv], $1006 \mathrm{~s}$.

Współoprawne $z$ :

Soto Domingo de: De natura et gratia, libri tres... - Venetiis: apud Floravantem à Prato, $1584.4^{\circ}$. [xvi], 301, [1] s.

B: skóra cielęca, tłoczenie na ślepo i złotem, brak klamer. Okladzina dolna: w ozdobnym kartuszu herb Lubicz odm., dewiza w otoku: Frustra vivit qui nemini prodest, tłoczenia: MATHEUS BRESTENSIS DOCTORIS THEOLOGIAE - XVI w.

\section{Pr.: 1. jw.}

2. Ex libris Alexandri Antonii Zabinski emptus 2 May 16...

3. Collegio Varsavi. Soc. Jesu. [= jezuici - Warszawa].

Sygnatura: NLR: 10.19.3.21.

Literatura: Józef Muczkowski, Statuta nec non Liber promotionum philosophorum ordinis in universitate studiorum Jagiellonica ab anno 1402 ad annum 1849, Kraków 1849, s. 228 [Matthaeus Wolski Brestensis]; Album Studiosorum Universitatis Cracoviensis, ed. Adam Chmiel, t. 1-3, Kraków 1892-1896, t. 3, s. 130. 
Nb. jezuitą był Brzestensis (Brestensis) Feliks ur. ok. 1583 r. na Kujawach, wst. $1603 \mathrm{w}$ Krakowie zm. $1636 \mathrm{w}$ Gdańsku, socjusz misjonarza dworskiego u biskupa kujawskiego 1618-19. Mateusz Wolski, nobilitacja 1591 h. Rawa, Kasper i Bartłomiej Wolscy 1592 adoptowani do h. Lubicz przez krewnych ze strony matki, zob. Materiaty genealogiczne, nobilitacje, indygenaty w zbiorach Archiwum Gtównego Akt Dawnych w Warszawie, oprac. Anna Wajs, Warszawa 1995, s. 128.

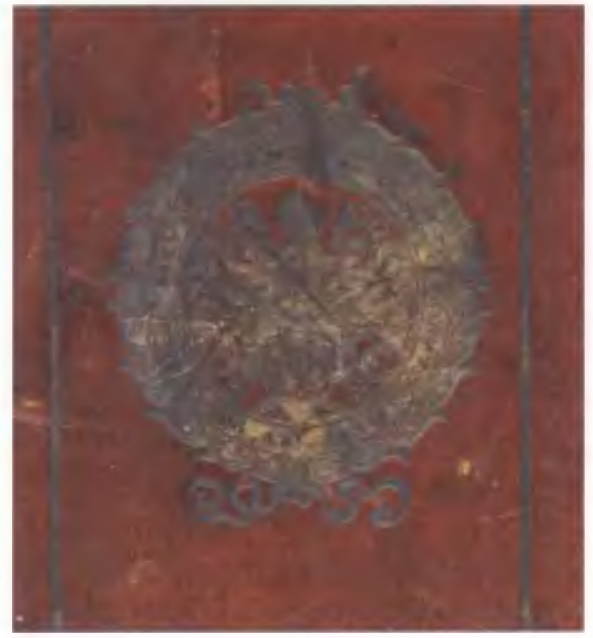

\section{Bużeński Hieronim ok. 1513-1580,}

herbu Poraj, żupnik krakowski, podskarbi wielki koronny, kasztelan sieradzki.

Sleidanus Johannes: De statu religionis et reipublicae, Carolo Quinto, caesare, commentarii... - Argentorati: excudebant Ribelii Fr., 1556. $2^{\circ}$. [IV], 390, [6] k.

B: deska, skóra cielęca, tłoczenie na ślepo i złotem, brak klamer. Na obu okładzinach w ozdobnym kartuszu herb Poraj, dewiza w otoku: Dominvs adivtor mevs et protector mevs 155II [1552], tłoczenia nad tarczą: I[eronymus] $\mathrm{B}$ [użeński].

Pr: 1. jw. oraz opisany wyżej herb i dewiza, poniżej: IN ARMA GENEROSI DOMINI HIERONIMI BUZENSKII, DE BUZENIN, ZUPPARII CRACOVIEN: S.R.M. SECRETARII. \&c. Hexastichon - ekslibris.

Sygnatura: NLR: 12.18.2.44.

Literatura: PSB, t. 3 s. 156-157; M. Sipayllo, dz. cyt., tabl. 18. 


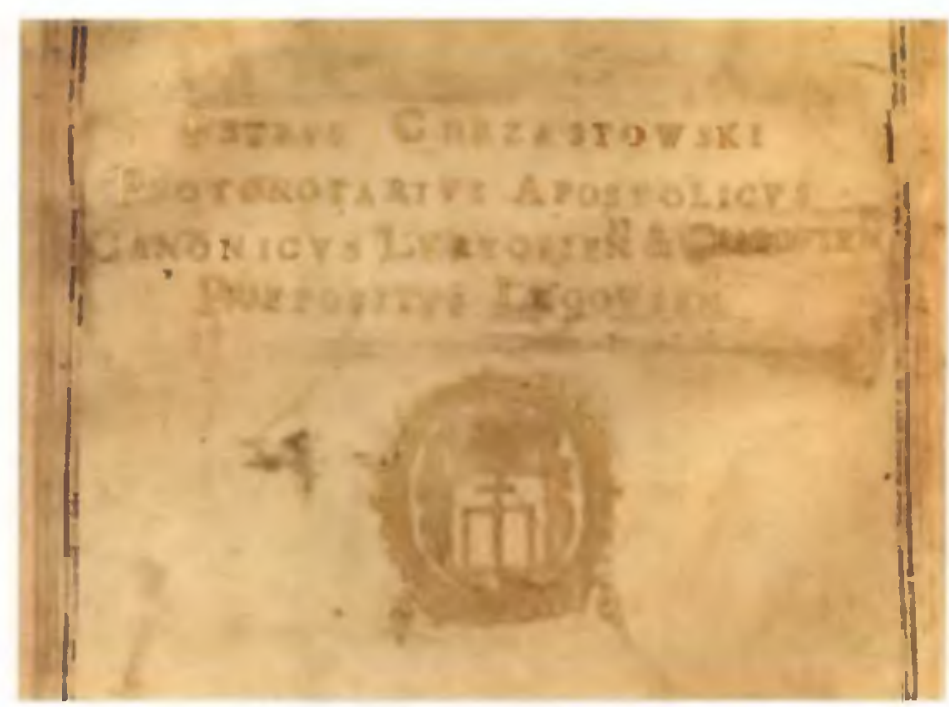

\section{Chrząstowski Piotr 1623,}

herbu Radwan, kanonik krakowski, łucki 1623, protonotariusz apostolski, proboszcz w Łagowie.

Calepino Ambrogio: Lexicon adauticum et recognitum denuo... - Haganoae: communibus Francisci Byrcman et Ioannis Cnoblochi impensis, Henricus Granius excudebat, 1526. $2^{\circ}$. 413 s.; brak końca po s. 407.

B: pergamin, tłoczenia na ślepo i złotem. Okładzina górna: w ozdobnym kartuszu herb Radwan na tarczy renesansowej, okolony wieńcem $z$ liści laurowych, powyżej tłoczenia: PETRVS CHRZĄSTOWSKI PROTONOTARIVS APOSTOLICVS CANONICVS LVCEORIEN \& CRACOVIEN PRAEPOSITVS LAGOVIEN. - XVII w.

Pr.: 1. jw.

2. Ex libris Monast. S. Crucis in Calvo Monte [= benedyktyni - Łysa Góra].

Sygnatura: NLR: 7.50.2.9.

Literatura: por. M. Sipayłlo, dz. cyt., tabl. 77 (inna wersja). 


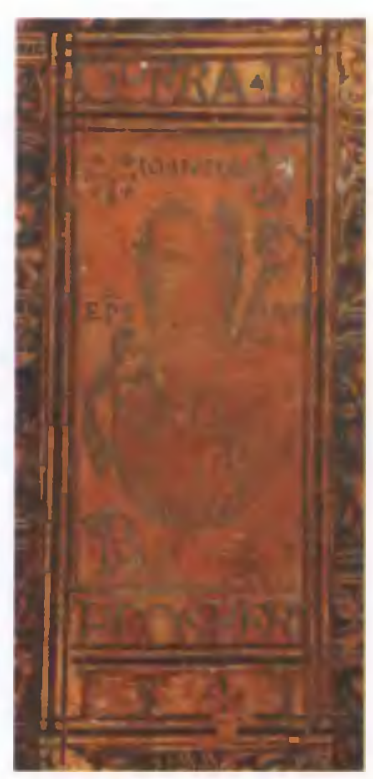

\section{Dantyszek Jan (von Höfen, Flaschbinden) 1485-1548,} herbu własnego, poeta nowołaciński, dyplomata, biskup warmiński.

Prosper d'Aquitaine s.: Opera... - Coloniae: ex officina Heronis Alopecii, 1540. $8^{\circ}$. [xvi], 856, [22] s.

B: deska, skóra cielęca, tłoczenie na ślepo i złotem, miedziane klamry. Na obu okładzinach, na tarczy czteropolowej herb własny oraz tloczenia: IOAN DAN EPS VAR $1536-1541$.

Pr.: 1. jw.

2. [Józef Andrzej Załuski] - znaki rps.

Sygnatura: NLR: 16.43.6.3.

Literatura: PSB, t. 4, s. 424-430; M. Sipayłlo, dz. cyt. tabl. 6. 


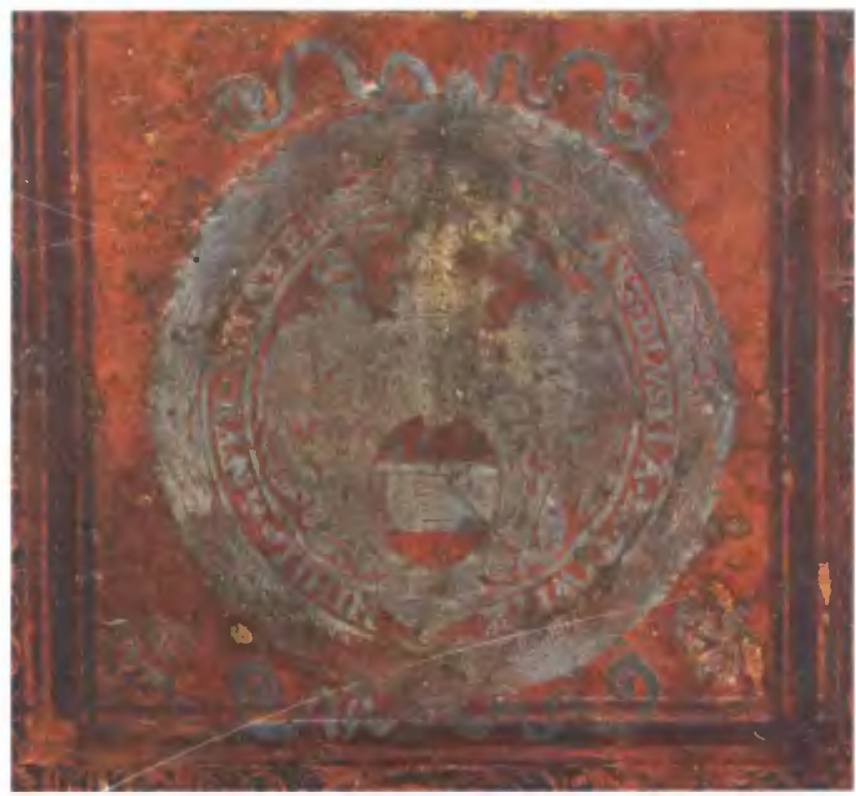

\section{Dhuski Mikołaj ok. 1540-1584,}

herbu Kotwicz, syn Andrzeja i Agnieszki z Myszkowskich, dziedzic Iwanowic, działacz reformacyjny, poseł na sejmy, surogator grodzki krakowski.

Origenes: Scripturarum interpretis opera... - Basilea: ex officina Frobeniana, 1545. $2^{\circ}$. [xxiv], $883 \mathrm{~s}$.

B: skóra cielęca (brak grzbietu), tłoczenie na ślepo i złotem. Okładzina górna: plakieta (św. Marek $z$ lwem) oraz w ozdobnym kartuszu herb Kotwicz, dewiza w otoku: Nicolavs Dlvski a Kottwicz nihil ante a[bb?]atem (wytarte) - XVI w.

Pr.: 1. jw.

2. Bibliothecae Cracoviensis S. Maria Canonicorum IRegularium de Paenitentia] BB. Martyrum [= kanonicy regularni od pokuty - Kraków].

Sygnatura: NLR; 16.59.1.29.

Literatura: PSB, t. 5, s. 195-197. 


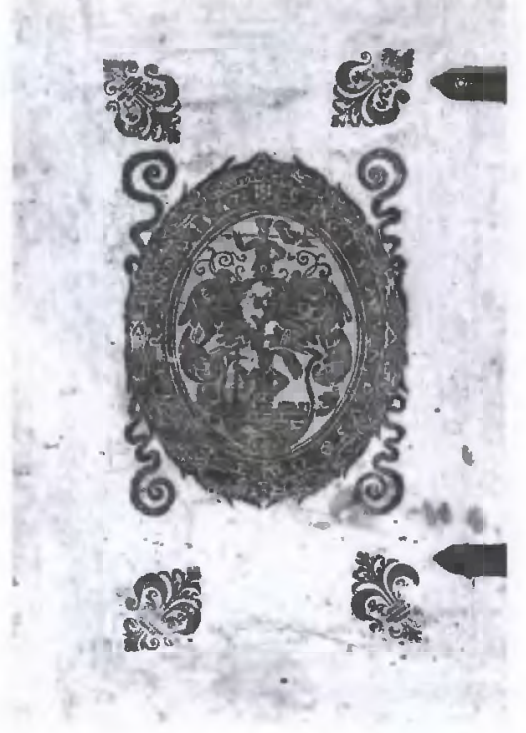

9. Gutteter Zygmunt zm. 1591, herbu własnego, doktor obojga praw, rajca i wielokrotny burmistrz Krakowa, członek zboru ewangelickiego.

Dictys Cretensis: Belli Troiani scriptores praecipui, Dictys Cretensis, Dares Phrygius \& Homerus... donati... - Basileae: per Petrum Pernam, 1573. $8^{\circ}$. [xvi], 1042 s.

B: skóra świńska, tłoczenie na ślepo i złotem, resztki klamer, obcięcia barwione czerwono. Okładzina górna: herb własny, w otoku: Sigismvndvs Gvtteter Anno 1567.

Sygnatura : NLR: 7.31.7.7.

Literatura: PSB, t. 9, s. 191. 


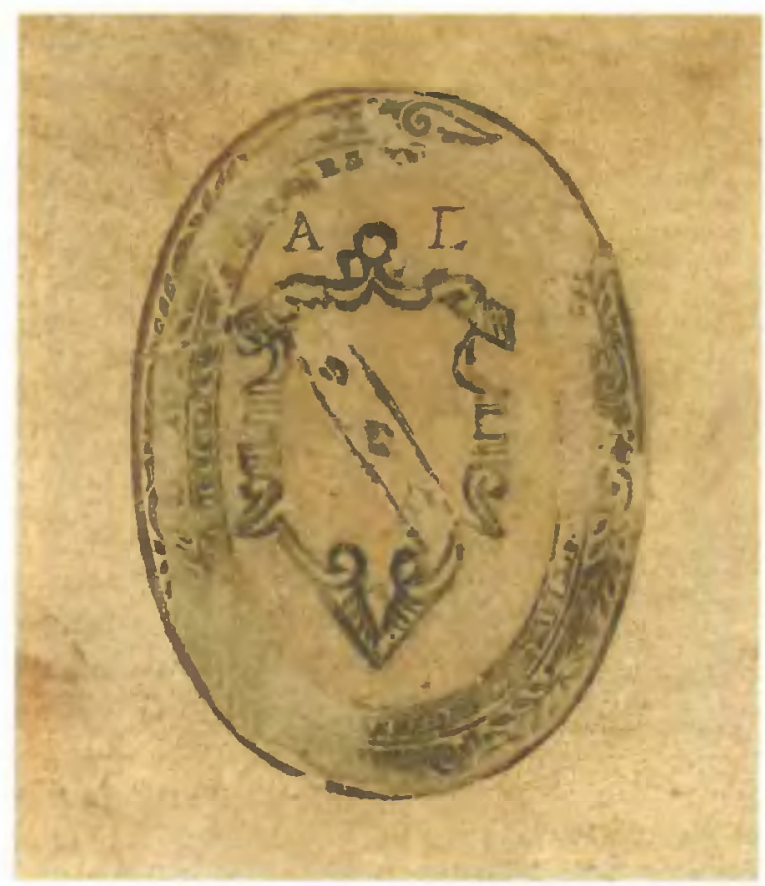

\section{Lisiecki Andrzej ok. 1576-1639,}

herbu Dryja, adwokat, instygator korony, pisarz.

Goryński Piotr: Statuta Ducatus Mazoviae... - Cracoviae: per Hieronymum Vietorem, 1541. $2^{\circ}$. [i], CXLII k.; brak karty tytułowej i pierwszej karty tekstu.

B: pergamin, tłoczenie na ślepo i złotem, obcięcia barwione czerwono. Okładzina górna: w kartuszu herb Dryja (superekslibris I wariant 2), dewiza w otoku: Alciora te ne scrvtatvsfveris sed qvae praecepit tibi dominvs cogita Ecclesiati [cus] 3:1583 (? wytarty), ponad kartuszem tłoczenia: A[ndreas] L[isiecki].

Pr.: 1. jw. oraz ekslibris typograficzny (zob. Opalińska, il.1).

2. Jnscriptus Catal. Librorum Coll. Caliss. Soc/ieta]tis Jesu. An. 1636 [= jezuici-Kalisz].

Sygnatura: NLR: 10.22.1.170.

Literatura: por. M. Sipayłlo, dz. cyt. tabl. 70, 71; K. Opalińska, Instygator koronny Andrzej Lisiecki $i$ jego ksiegozbiór, w: Ksiegozbiory szlacheckie XVI-XVII wieku, Warszawa 2004, il. 3 (superekslibris I war. 1). 


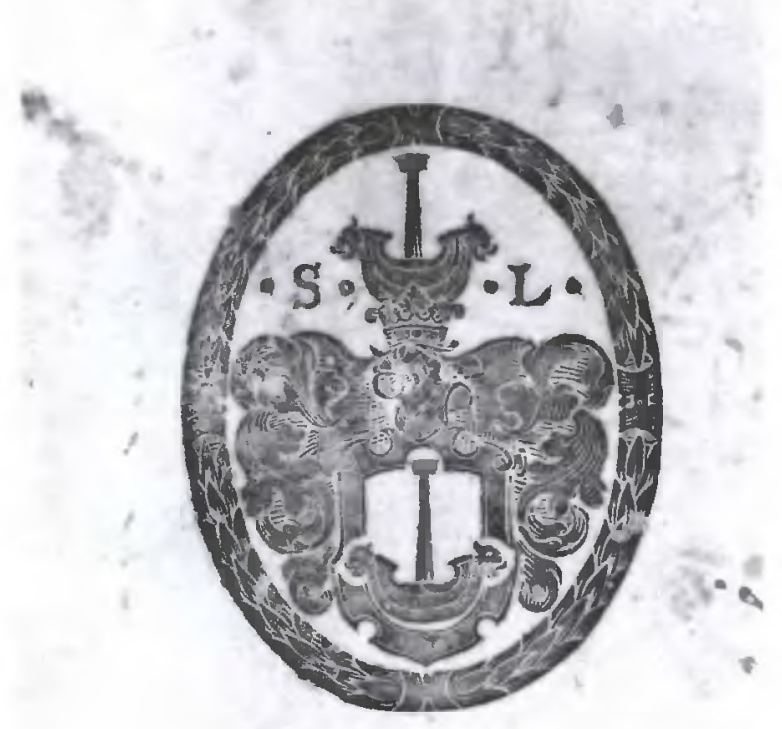

\section{1. Łaski Samuel po 1553-1611,}

herbu Korab, syn Jana ml. reformatora, podróże do Anglii i Francji (Orlean), rotmistrz, sekretarz królewski, dyplomata.

Guicciardini Francesco: La Historia d'Italia... divisa in venti libri... - Venetia: Domenico Farri, 1587. $4^{\circ}$. [xlviii], 488, $111 \mathrm{k}$.

B: pergamin, tłoczenie zlotem. Na okładzinie górnej herb Korab, powyżej tłoczenia: S[amuel] L[aski] - XVI/XVII w.

Pr.: 1. Abrachamus Ortelius - XVI w.

2. jw.

Sygnatura: NLR: 12.14.6.63.

Literatura: PSB, t. 18, s. 250-252; M. Sipaylło, dz. cyt., tabl. 58. 


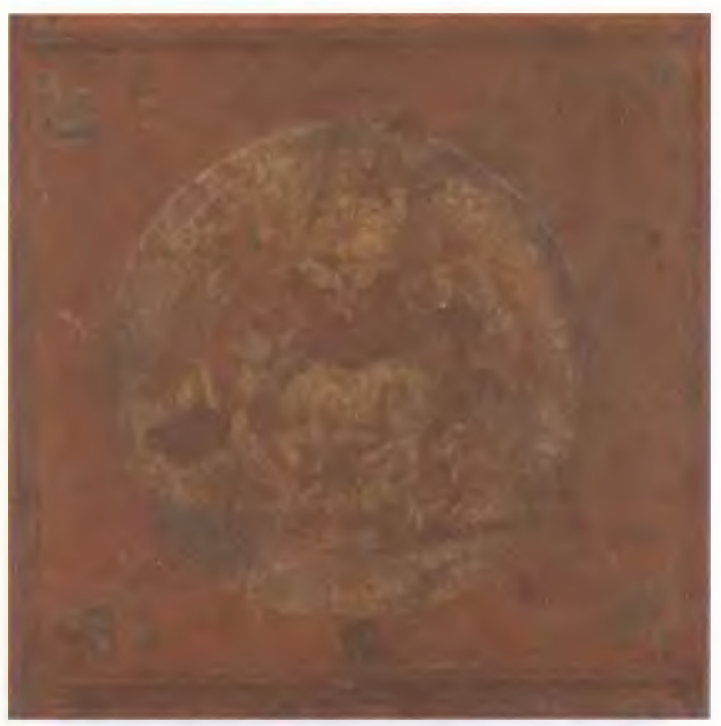

\section{Maciejowski Samuel 1499-1550,}

herbu Ciołek, biskup krakowski, kanclerz wielki koronny.

Absalon Sprinckirsbacensis: Sermones festivales eruditi... cura D. Danielis Schillinckii... - Coloniae: apud Ioannem Gymnicum, 1534. $2^{\circ}$. [xvi], $174 \mathrm{~s}$.

B: deska, skóra cielęca, tloczenie na ślepo i złotem. Okładzina dolna: w kartuszu herb Ciołek, nad kartuszem insygnia biskupie, poniżej data: MD XLVI [1546], w otoku: Samvel Macieiowski D: G: Epvs Cracovien. \& Regni Po: Vicecancel. Okładzina górna: plakieta Ukrzyżowanie.

Pr.: 1. jw.

2. Convent. Crac. S. Spũs et S. Crucis [=kanonicy regularni Ducha Świętego de Saxia - Kraków].

Sygnatura: NLR: 16.80.1.20.

Literatura: Kazimierz Piekarski, Superexlibrisy polskie od XV do XVIII wieku. Kraków 1929, tabl. 15 (superekslibris II).

$Z$ badań nad książką i księgozbiorami historycznymi, 3:2009 


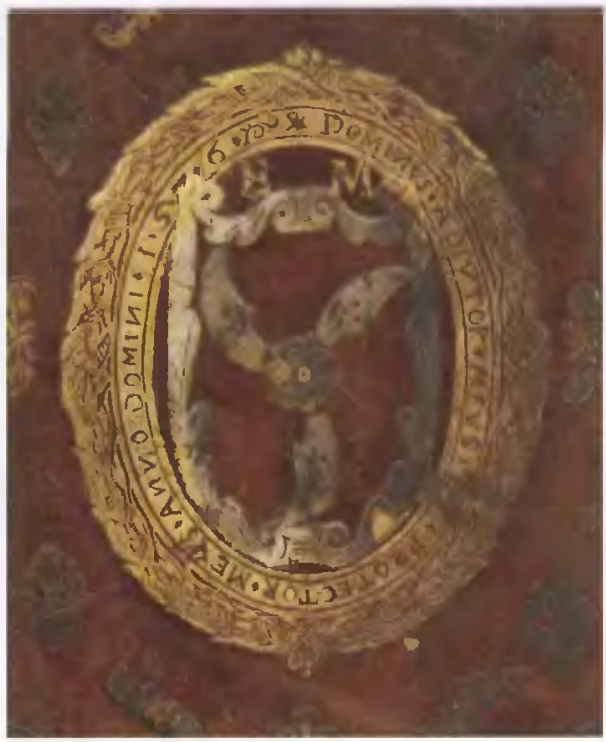

\section{Marcinowski Erazm zm. 1591}

herbu Rola, syn Marcina, mgr Akademii Krakowskiej 1576, święcenia kapłańskie 1583-1584, kaznodzieja kolegiaty tarnowskiej.

Cardano Girolamo: De rerum varietate libri XVII, a prima editione ab ipso denuo authore recogniti... Avinione: per Matthaeum Vincentium, 1558. $8^{\circ}$. [xiv], 883, [48] s.; il.

B: deska, skóra cielęca, tłoczenie na ślepo i zlotem, ślady po klamrach, obie okładziny zdobią złocone bordiury okalające zwierciadło, w centrum złocona plakieta w owalu $z$ motywem arabeski oraz medalion. Okładzina dolna: $w$ kartuszu herb Rola, powyżej tłoczenia literowe: E[rasm] M[arcinowski], dewiza w otoku: Dominvs Avditor mevs et protector mevs Anno Domini 1576 (superekslibris III), tłoczenia: ERASMUS MARCZINOWSKI .

Pr.: 1. jw.

2. Conv. Craco. Carme. Discal. [= karmelici bosi - Kraków].

3. L[yceum] V[arsaviense] - XIX w.

Sygnatura: NLR: 36.39.3.6.

Literatura: por. K. Piekarski, dz. cyt., s. 16-17 (superekslibris I - II). 


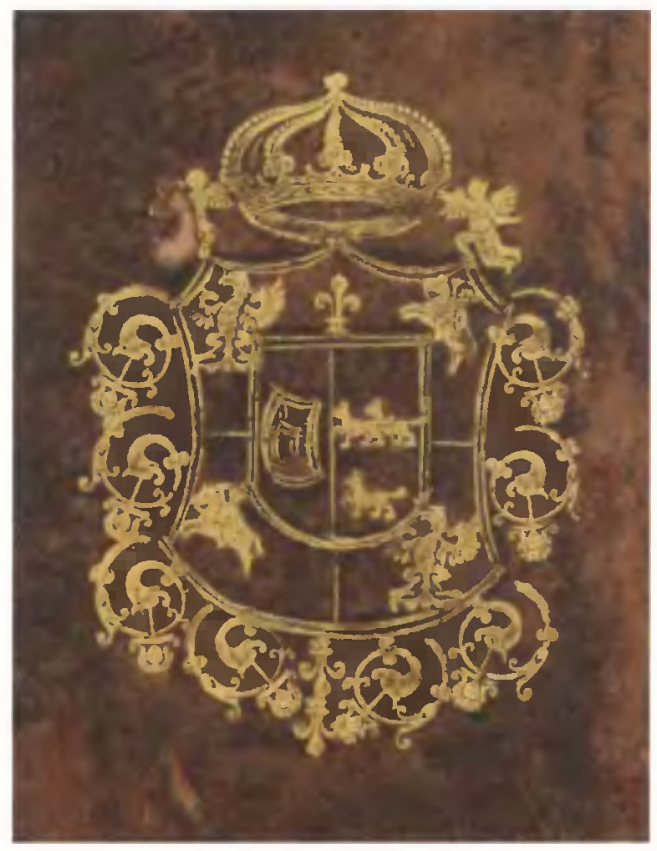

\section{Maria Kazimiera de la Grange d'Arquien 1641-1716,} królowa polska, żona Jana III Sobieskiego.

Bassani Antonio: Viaggio à Roma raleta della S. R. M. Maria Casimira... per il voto di visittare... Innocenzo XII... Roma: Nella Stamperia Barberini, impresse Domenico Antonio Ercole in Parione, $1700.4^{\circ}$. [x], 226, [2] s.; karta tytułowa miedzioryt.

B: skóra cielęca trawiona, grzbiet bogato zlocony we wzory roślinne, gwiazdy $\mathrm{i}$ liście, bordiura: podwójne złocone linie strychulcem, kwiatony w narożach. $\mathrm{Na}$ obu okładzinach zlocona tarcza herbowa 6-polowa: herby Korony i Litwy (Orzeł i Pogoń) ułożone na przemian, w polu sercowym tarcza 2-polowa $z$ h. Janina Sobieskich i h. wlasnym d'Arquien. Oprawa donacyjna - XVII/XVIII w.

Sygnatura: NLR: 12.4.8.13.

Literatura: PSB, t. 19, s. 637-644. 


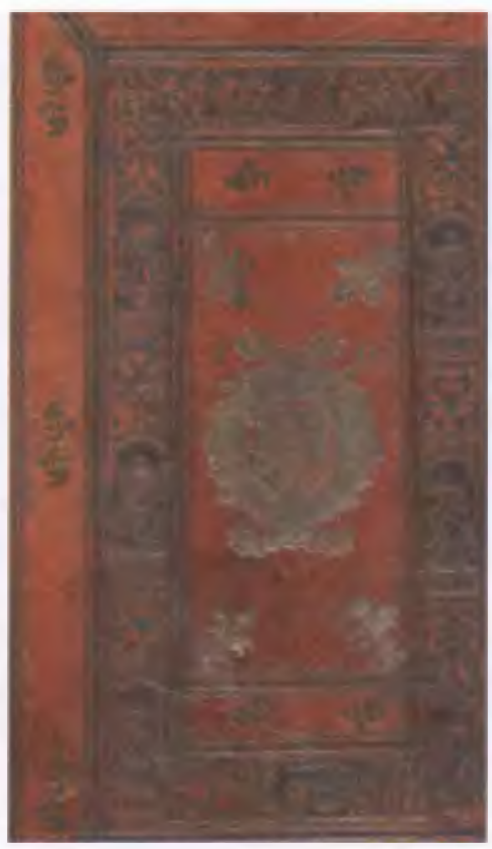

15. Myszkowski Jakub zm. 1571,

herbu Jastrzębiec, syn Macieja i Zuzanny $z$ Łaskich (siostry Jana reformatora), burgrabia krakowski 1564, działacz reformacyjny.

Sleidan Jean: De statu religionis et reipublicae, Carolo Quinto, caesare, commentarii... - Argentorati: excudebant Ribelij Fr., 1556. $2^{\circ}$. [IV], 390, [38] k.

B: deska, skóra cielęca, tłoczenie na ślepo i złotem, brak klamer. $\mathrm{Na}$ obu okładzinach w kartuszu herb Jastrzębiec, powyżej tłoczenia: I[acobus] M[yszkowski], dewiza w otoku: Virtvs ardva petit Anno d[omini] MDLI [1551].

Pr. 1. Anno Domini 1558 die undecima mensis Julij In villa Cristoporska wolija Circa sepulturam Generosi dlomilni Domini Petri Cristoporskj domini et amici mei singulari fide observandj et Generoso Domino Jacobo Miskowski in vim singularis et mutui amoris donatus [Jan Krzysztoporski st.].

2. jw.

Sygnatura: NLR: 12.18.2.40.

Literatura: por. M. Sipaylło, dz. cyt., tabl. 22 (z inicjałami: S M). 


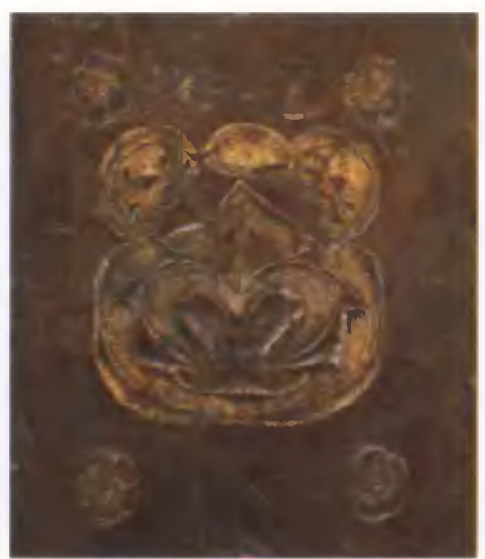

16. N L (XVI w.), herbu Odrowąz, niezidentyfikowany.

Georgius Trapezuntius: Rhetoricorum libri... - Basileae: Valentinus Curio, 1522. $4^{\circ}$. [vi], $175,[1] \mathrm{k}$.

B: skóra cielęca, tłoczenie na ślepo i złotem. Okładzina dolna: w kartuszu herb Odrowąz, powyżej tłoczenia: N (odwrócone) L-XVI w.

Pr.: 1. jw.

2. Ex libris Alberti Brzezinii artium et philosophiae baccalaurei - XVI w.

3. Biblioth. C.R.L. Mstovien. [= kanonicy regularni lateraneńscy - Mstów].

4. L[yceum] V[arsaviense] - XIX w.

Sygnatura: NLR: 7.27.2.10.

Z badań nad książką i księgozbiorami historycznymi, 3:2009 


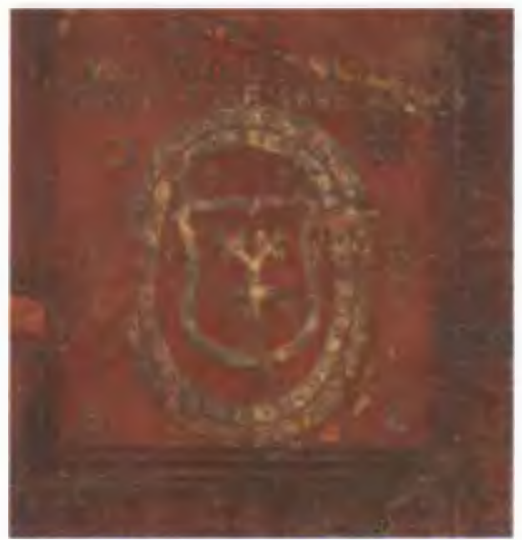

\section{Piltowski Florian zm. 1601,}

herbu Brodzicz, proboszcz i oficjal kielecki, scholastyk opatowski 1581.

Clichtoveus Jodocus: Elucidatorium ecclesiasticum ad officium ecclesiae pertinentia... - Parisiis: in officina Henrici Stephani, 1516. $2^{\circ} .227$, [1] k.

B: deska, skóra cielęca, tłoczenie na ślepo i złotem, brak klamer. Okładzina dolna: w kartuszu herb Brodzicz, powyżej tloczenia: F[lorianus] P[iltowski] S[cholasticus] O[patoviensis], dewiza w otoku: Frvstra vivit qvi nemini prodest 1566 (superekslibris III).

Pr.: 1. jw. oraz Florianus Pilchowski, Artium Baccalaureus Scholastic. Opatoweñ 1592 Aug. Prima.

2. Convent. Opatowiens. [= bernardyni - Opatów].

Sygnatura: NLR: 15.17.1.199.

Literatura: por. M. Sipayłlo, dz. cyt., tabl. 40-41 (biogram s. 112). 


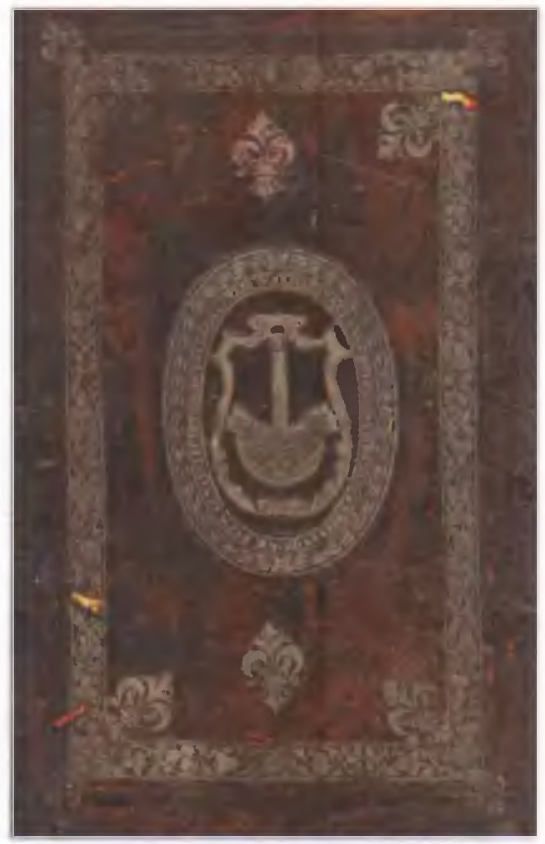

18. Poradowski Andrzej 1580,

herbu Korab z Poradowa [?] w ziemi rawskiej, syn Mikołaja, wpisany do metryki studentów Akademii Krakowskiej 1548, synowie: Albert, Jan i Jerzy wpisani do metryki studentów Akademii Krakowskiej 1583.

Mynsinger Joachim: Apotelesma, sive corpus perfectum scholiorum ad quatuor libros Institutionum iuris civilis... - Basileae: per Eusebium Episcopium, \& Nicolai fratris haeredes, 1580. $2^{\circ}$. [xx], 590, [53] s.

B: deska, skóra cielęca ciemna, tłoczenie na ślepo i złotem, brak klamer, miedziane okucia narożników (zachowane częściowo). Okładzina górna: bordiura, w centrum zwierciadła owalna plakieta $z$ motywem arabeski oraz tłoczenia: ANDREAS PORADOWSKI, okładzina dolna: na tarczy herb Korab, dewiza w otoku: Alciora te ne scrvtatvs fveris sed quae praecepit tibi dominvs cogita Eccle. 3[,22] - XVI w.

Pr.: 1. jw.

2. Biblioth. C.R.L. Mstovien. [= kanonicy regularni lateraneńscy - Mstów].

Sygnatura: NLR: 10.105.23.

Literatura: Album Studiosorum, op. cit., t. 2, s. 335, t. 3, s. 134. 


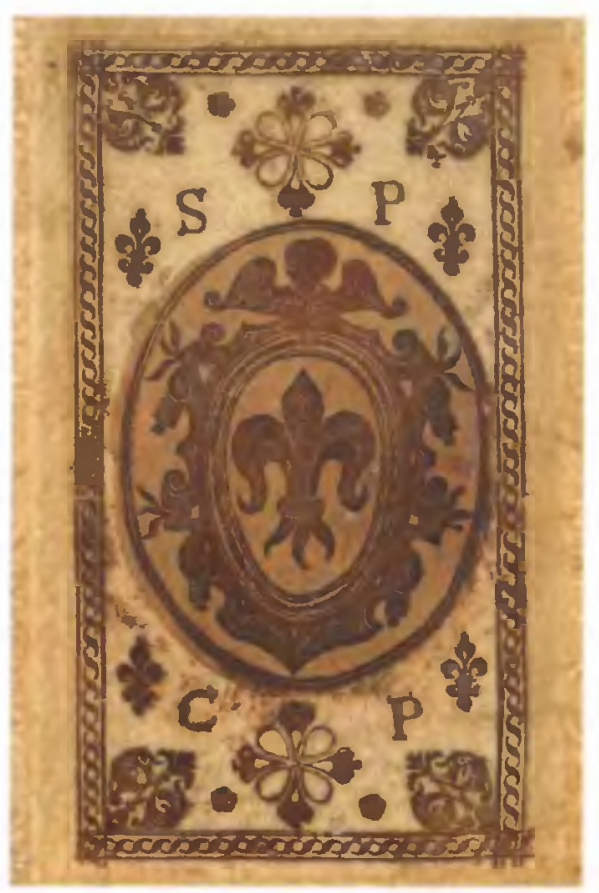

\section{Poznański (Posnaniensis) Sebastian zm. 1638, herbu Gozdawa, kanonik pultuski.}

Menochio Jacopo: De adipiscenda, retinenda et recuperanda posessione, doctissima commentaria... - Coloniae Agrippinae: apud haeredes Ioannis Gymnici sub Monocerote, 1599. $2^{\circ}$ [lxvi], 467, [1] s.

Współoprawne $\mathrm{z}$ :

Verallo Paolo Emilio: Aurearum decisionum causarum Sacri Palatii Apostolici... libri tres... - Francofurti: ex Officina Typographica Nicolai Hoffmanni, 1607. $2^{\circ}$. [iv], 299, [53] s.

B: deska, skóra świńska, tłoczenie na ślepo i złotem, wiazania skórzane. $\mathrm{Na}$ górnejokładzinie herb Gozdawa, powyżejtłoczenia:S[ebastianus] P[osnaniensis] C [anonicus] P[ultoviensis] ${ }^{1}-\mathrm{XVI} / \mathrm{XVII} \mathrm{w}$.

Sygnatura: NLR: 10.105.63.

${ }^{1}$ Identyfikacja Marii Cubrzyńskiej-Leonarczyk; w zbiorach BUW znajduje się identyczny znak z zapisem własnościowym kościoła kolegiackiego w Pułtusku. Ponadto w Katalogu zabytków sztuki w Polsce, T. 10, z. 20, Warszawa 1990, il. 318, opublikowano jego nagrobek z h. Gozdawa. 


\section{Próchnicki Jan Andrzej 1553-1633,}

herbu Korczak, arcybiskup lwowski, dyplomata, mecenas, bibliofil.

Gruter Jan: Lampas, sive fax artium liberalium, hoc est: thesaurus criticus... - Francofurti: e Collegio Paltheniano, sumptibus Ionae Rhodii, 1604. $8^{\circ}$. T. IV. [vi], 914 s.; brak karty tytułowej.

B: deska, skóra świńska, tłoczenie na ślepo i zlotem, brak klamer, miedziane okucia narożników. Na obu okładzinach herb Korczak, nad kartuszem insygnia biskupie, dewiza w otoku: Pietate religione virtvte, niżej napis: Io[annes] An[dreas] Prochnicki P (właściwie:) E[piscopus] C[amenecensis], superekslibris IV (według Gębarowicza) - XVII w.

\section{Pr.: 1. jw.}

2. L[yceum] V[arsaviense] - XIX w.

Sygnatura: NLR: 7.23.3.16.

Literatura: Mieczysław Gębarowicz, Jan Andrzej Próchnicki (1553-1633), Kraków 1980, s. 206-207, il. 10; por. M. Sipayłlo, dz. cyt., tabl. 61 (odm. III). 


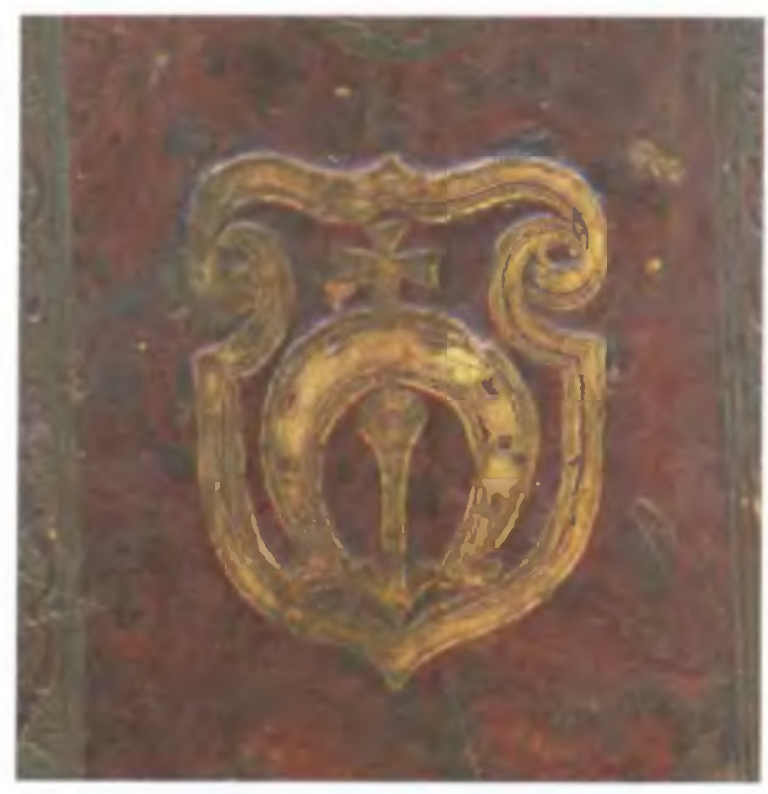

\section{Sierakowski Mikołaj ok. 1470-1543,}

herbu Dołęga ze Starego Sierakowa na Mazowszu, podżupnik bocheński, sędzia grodzki krakowski.

Vocabularius utriusq[ue] juris. - Hagenau: in officina industrij Henrici Gran, 1508. $2^{\circ}$. [128] k.

B: deska, skóra cielęca barwiona wiśniowo, tloczenie na ślepo i zlotem, brak klamer, okładzina dolna: w kartuszu herb Dołega, tłoczenie: NICOLAUS SIRAKOWSKI - XVI w.

Pr.: 1. jw.

2. Huius libri possesor Reverendus Matias Kranczki[?] - XVI w.

3. Ex libris Stephani Mietelskil?] Condonat. à F. Josepho Salewski. 1636.

Sygnatura: NLR: 10.1.2.69.

Literatura: PSB, t. 37, s. 291-292. 


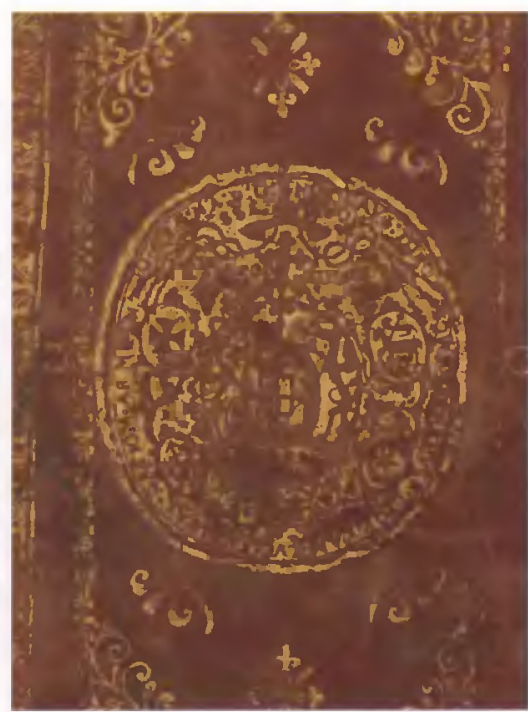

\section{Torosowicz (Torosiewicz) Mikolaj 1602-1681,}

herbu własnego, pierwszy unicki metropolita lwowski obrządku ormiańskiego.

Treter Tomasz: Romanorum Imperatorum effigies... - Romae: apud Vincentium Accoltum, 1573. $8^{\circ}$. [xii], $157 \mathrm{k..;}$ karta tytułowa i il. miedzioryt.

B: skóra cielęca barwiona wiśniowo, tłoczenie złotem, obcięcia złocone, kompozycja herbowa zlożona $z 5$ herbów pod kapeluszem biskupim, w polu centralnym herb własny, poniżej data: 1665 , w otoku: Nicolavs Torosowicz Ar[chi]e[pisco]pus Leop[oliensis] Kam[enecensis] Lvc[eoriensis] Kio[viensis] Wal[achiensis] etc.

Pr.: 1. jw.

2. [Józef Andrzej Załuski] - znaki rps., XVIII w.

Sygnatura: NLR: 33.92.1.49.

Literatura: ks. Sadok Barącz, Żywoty stawnych Ormian w Polsce, Lwów, 1856, s. 332-337. 


\section{Wolski-Dunin Piotr 1531-1590,}

herbu Łabędź, biskup płocki, kanclerz wielki koronny, dyplomata, bibliofil.

Fulgentius Afer, ep. Ruspensis s.: Opera... - Antverpiae: apud Christophorum Plantinum, $1573.8^{\circ} .691 \mathrm{~s}$.

B: skóra świńska, tłoczenie na ślepo i złotem, obcięcia barwione czerwono, klamry (brak jednej). Na obu okładzinach w kartuszu herb Łabędź z insygniami biskupimi, w otoku: Petrvs Dvnin Wolsky D[ei] G[ratia] Episcopvs Plocensis $-\mathrm{XVI}$ w.

Pr: 1. jw.

2. [Józef Andrzej Załuski] - znaki rps., XVIII w.

Sygnatura: NLR: 16.41.6.37.

Literatura: M. Sipayłlo, dz. cyt., tabl. 47. 


\section{Wolski Maciej Augustyn 1665,}

herbu Sternberg, doktor teologii, sekretarz królewski, kanonik regularny zakonu bożogrobców, kanonik kamieniecki.

Luzon de Millares Alexander: Idea politica veri christiani, sive ars oblivionis, isagogica ad artem memoriae. - Bruxellis: typis Francisci Foppens, 1665. $2^{\circ}$. [xvi], 674, [1] s.; il.

B: pergamin, grzbiet gładki, tłoczenie złotem, na obu okładzinach tarcza dwudzielna $z$ godłem bożogrobców oraz herbem Sternberg pod kapeluszem opackim, w otoku: Augustin Wolski S. Th[eologiae] D[octor] Prot[onotarius] Ap[osto]l[icus] can[onicus] ca[me]ne[censis] praep[ositus] hed[vigis] co[ncionator] - XVII w.

Pr. 1. jw.

Sygnatura: NLR: 36.12.1.6.

Literatura: Maria Cubrzyńska-Leonarczyk, Polskie superekslibrisy XVI-XVII wieku w zbiorach Biblioteki Uniwersyteckiej w Warszawie. Centuria druga, Warszawa 2001, tabl. 92 (po 1689). 


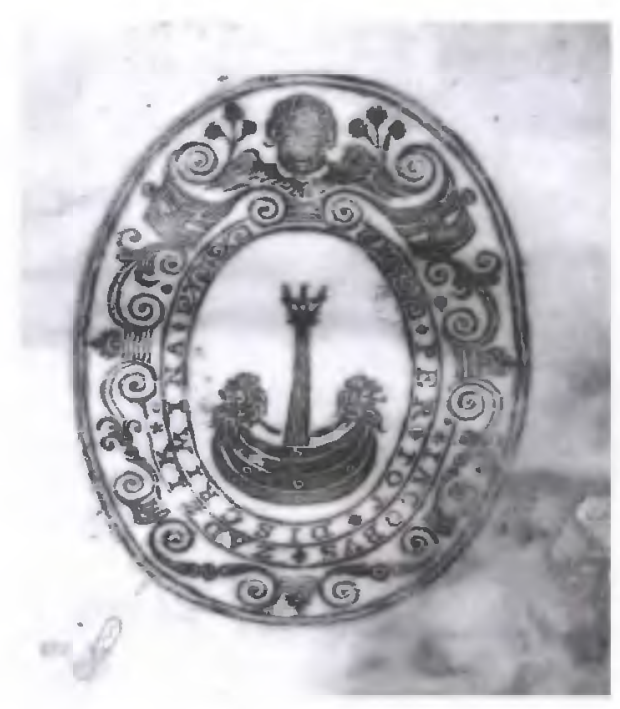

25. Zadzik Jakub 1582-1642,

herbu Korab, kanclerz wielki koronny, biskup krakowski.

Bartholinus Riccardus: Ad Divum Maximilianum Caesarem Augustum... De bello Norico Austriados libri duodecim. - Argentorati: ex aedibus Matthiae Schurerii, 1516. $8^{\circ}$. [173] k.

B: pergamin, tłoczenie złotem, na obu okładzinach herb Korab, w otoku: Per tot discrimina lacobvs Zadzik - XVII w.

Pr.: 1. jw.

2. Casimiri a Lasko... [?] - XVII w.

Sygnatura: NLR: 6.2b.6.56.

Literatura: K. Piekarski, dz. cyt., s. 39 (superekslibris I, ok. 1620).

THumaczenie i redakcja: Marianna Czapnik 